\title{
Magnesium Doped Hercynite: Preparation and Formation Mechanism
}

\author{
Hossien RAHMANI-BOLDAJI, Mohammad-reza SAERI *, Sasan OTROJ, Hassan SHARIFI
}

\author{
Department of Materials Engineering, Faculty of Engineering, Shahrekord University, Shahrekord, Iran \\ crossref http://dx.doi.org/10.5755/j01.ms.24.3.17915
}

Received 10 April 2017; accepted 17 October 2017

\begin{abstract}
We investigated the formation mechanism of magnesium doped hercynite during reaction sintering process at $1400{ }^{\circ} \mathrm{C}$. A two-step synthesis procedure based on combining of spinel and ferrous chloride was considered here. Firstly, magnesium aluminate spinel was prepared by sol-gel method, using $\mathrm{Al}$ and $\mathrm{Mg}$ chlorides as raw materials. Then, the powder particles were dispersed in an aqueous solution of ferrous chloride in 1.5:1 molar ratio and the solution was stirred at $60{ }^{\circ} \mathrm{C}$. After solvents removal, the thermal properties of a sample of the dried specimens were studied, using simultaneous thermal analysis (STA) method. Afterwards, the specimens were calcined at 400, 800, 1100 and $1400{ }^{\circ} \mathrm{C}$ for 1,3 and $6 \mathrm{hrs}$, under air atmosphere. X-ray diffraction (XRD) analysis, field emission scanning electron microscope (FESEM) and X-ray fluorescence spectroscopy (XRF) were used for characterization of the specimens. Study of the obtained results leads us to conclude that hercynite was formed thorough a diffusion-based mechanism, when heated to high enough temperatures. After heating for a prolonged period $\left(6 \mathrm{hrs}\right.$.) at $1400^{\circ} \mathrm{C}$, hercynite decomposes into its constituent oxides and also a new crystal phase appears. This new phase was identified as $\mathrm{FeAlO}_{3}$. The modified Scherrer, Williamson-Hall and Rietveld methods are also used to estimate the crystallite size of the as-synthesized magnesium doped hercynite. Key Words: hercynite; spinel; formation mechanism; calcination.
\end{abstract}

\section{INTRODUCTION}

Hercynite $\left(\mathrm{FeAl}_{2} \mathrm{O}_{3}\right)$ is a mixed oxide compound with normal spinel structure. The normal spinel structure is known with its general formula $\mathrm{AB}_{2} \mathrm{O}_{4}$ and huge unit cell that includes eight face centered cubic (FCC) units where $\mathrm{A}$ and $\mathrm{B}$ are 2 and 3 valence cations respectively and $\mathrm{O}$ is oxygen. The 3 valence cation occupies octahedral sites and the 2 valence one sits in tetrahedral sites while oxygen occupies FCC sites. In this structure one eighth of tetrahedral sites are occupied by $\mathrm{Fe}^{2+}$ and half of octahedral sites are occupied by $\mathrm{Al}^{3+}$ cations $[1,2]$. The most common method of preparing hercynite is heating of initial oxide mixture $\left(\mathrm{Fe}_{2} \mathrm{O}_{3} \& \mathrm{Al}_{2} \mathrm{O}_{3}\right)$ at high temperatures $\left(>1300{ }^{\circ} \mathrm{C}\right)$ for extended period (16 hrs) in oxygen partial pressurecontrolled atmosphere [3]. Hercynite can be used in various applications such as chrome free magnesia refractory bricks for cement rotary kilns (magnesia-hercynite bricks) [4], ceramic bounding in $\mathrm{MgO}-\mathrm{CaZrO}_{3}$ refractories [5] and ceramic pigments [6]. Besides, it has attracted extensive interests due to its potential application as a magnetic material [7]. The major drawbacks of producing of hercynite are the need of high temperature, entailed by the necessity of controlled atmosphere [1-7].

Botta et al. reported synthesis of hercynite from mechano-chemical activated method under an atmosphere of argon, using aluminum and magnetite as starting materials [3]. Chen et al. applied nitrogen gas flow in synthesis of hercynite by the reaction sintering method, using industrial alumina, mill scale $\left(\mathrm{FeO}+\mathrm{Fe}_{2} \mathrm{O}_{3}\right)$ and carbon black as raw materials. They found that only the sample heated at temperatures as high as $1550{ }^{\circ} \mathrm{C}$, could produce high purity and well crystallized hercynite [4].
Dutta and Sharma synthesized hercynite by heating of corresponding iron and aluminum acetylacetonate complexes [7]. Jastrzębska et al. prepared $\mathrm{FeAl}_{2} \mathrm{O}_{4}$ $\mathrm{MgAl}_{2} \mathrm{O}_{4}$ solid solution, using APS method. The product of their work was a compound of spinel with chemical formula as $\mathrm{Fe}^{2+}{ }_{0.699} \mathrm{Mg}_{0.301} \mathrm{Al}_{1.941} \mathrm{Fe}^{3+}{ }_{0.059} \mathrm{O}_{4}$ [8]. Sako et al. investigated magnesium aluminate (MA) spinel formation mechanism. They found that Kirkendall effect plays an important role during the in-situ formation of spinel [9]. Jastrzębska et al. [10] also suggested a mechanism for decomposition of hercynite into $\mathrm{Fe}_{2} \mathrm{Ol}_{2} \cdot \mathrm{Oe}_{3} \mathrm{O}_{4}, \mathrm{Fe}_{3} \mathrm{O}_{4}$ and $\gamma-\mathrm{Al}_{2} \mathrm{O}_{3}$, during heating at $1000{ }^{\circ} \mathrm{C}$ for $24 \mathrm{hrs}$.

Recently, Otroj [11] found that calcined alumina + hematite $+\mathrm{MgO}$ could form hercynite, using a reaction sintering process at temperature over $1450{ }^{\circ} \mathrm{C}$ under air atmosphere. Also, Baghaei et al. prepared hercynite by coprecipitation method, using $\mathrm{AlCl}_{3} \cdot 6 \mathrm{H}_{2} \mathrm{O}, \mathrm{FeCl}_{2} \cdot 4 \mathrm{H}_{2} \mathrm{O}$ and $\mathrm{MgCl}_{2}$ as raw materials [12]. They investigated the effects of addition of $\mathrm{MgO}$ on the formed hercynite. They reported that more addition of $\mathrm{MgCl}_{2}$ leads to the higher formation of hercynite, due to the increasing the amount of formation of spinel structure. In this article, along the line of our previous works [11, 12], a different wet mixing and blending was carried out before the reaction sintering of hercynite, using a solution of ferrous chloride and powder of MA spinel. Because crystal structure of hercynite is similar to that of MA spinel, therefore the similarity in their XRD patterns makes distinguishing them very difficult. So, we calculated the lattice parameter of specimen by using the Reitveld method, to ensure that hercynite is formed. To gather information about the mechanism of forming of magnesium doped hercynite, the effects of time and temperature of the reaction sintering were also studied.

\footnotetext{
${ }^{*}$ Corresponding author. Tel.: +98-38-32324438; fax: +98-38-32324438.

E-mail address: Saeri_mohammad@yahoo.com (M. Saeri)
} 


\section{EXPERIMENTAL}

A two-step synthesis procedure based on combining of spinel and ferrous chloride was considered here. Firstly, $\mathrm{MgAl}_{2} \mathrm{O}_{4}$ spinel was prepared by sol-gel method, using aluminum chloride (purity: > $98 \%$, Merck, Germany) and magnesium chloride (purity: > $99 \%$, Kimia Mavad, Iran) as raw materials. The aqueous reaction mixture contains stoichiometric amounts of aluminum and magnesium chlorides, was stirred at $60^{\circ} \mathrm{C}$ for $1 \mathrm{hr}$. The mixture was placed in a drying oven for $24 \mathrm{hrs}$ at $110^{\circ} \mathrm{C}$ and subsequently, the resulting yellow substance was calcined for 6 hours at $600{ }^{\circ} \mathrm{C}$. After milling the synthesized spinel powder in an alumina mill for $2 \mathrm{~h}$, the phase composition of the samples was investigated, using XRD method (Asenware AW-XDM300, $\mathrm{Cu}_{\mathrm{k} \alpha}$, China).

In the next step, the synthesized powder was dispersed in an aqueous solution of iron (II) chloride tetrahydrate (purity: > 99\%, Merck, Germany) in 1.5:1 molar ratio and the solution was stirred at $60{ }^{\circ} \mathrm{C}$, using a magnetic stirrer. The stirring was continued until all the water of solution was evaporated. After solvents removal, the thermal properties of a sample of the dried specimens were studied, using simultaneous thermal analysis (STA) method. The data obtained were used for the selection of the most appropriate thermal regimes of calcination. Afterwards, the dried specimens (the mixture of spinel and iron chloride) were calcined, at 400, 800, 1100 and $1400{ }^{\circ} \mathrm{C}$ for 1,3 and $6 \mathrm{hrs,}$ to study the effects of temperature and heating time on the formation of hercynite. Besides, FTIR spectroscopy (Hartman \& Braun MB-series 100, Canada) was carried out on the specimens, before and after the heating process.

The microstructure of the fired specimens was also investigated by FESEM (MIRA3 TESCAN, Czech), equipped with energy dispersive X-ray spectroscopy. Furthermore, the chemical compositions, determined by Xray fluorescence spectroscopy (XRF) (PW2404, PHILIPS). Finally, the phase compositions of the fired specimens were identified by $\mathrm{XRD}$, using $\mathrm{Cu}_{\mathrm{Ka}}$ radiation with a step size of $0.02^{\circ}$. The crystallite size of the synthesized hercynite was also calculated, using different XRD-based methods. For this purpose, Rietveld, Williamson-Hall and modified Scherrer methods were applied, using XRD patterns [13].

\section{RESULTS AND DISCUSSION}

Fig. 1 shows the X-ray diffraction (XRD) pattern of assynthesized MA spinel.

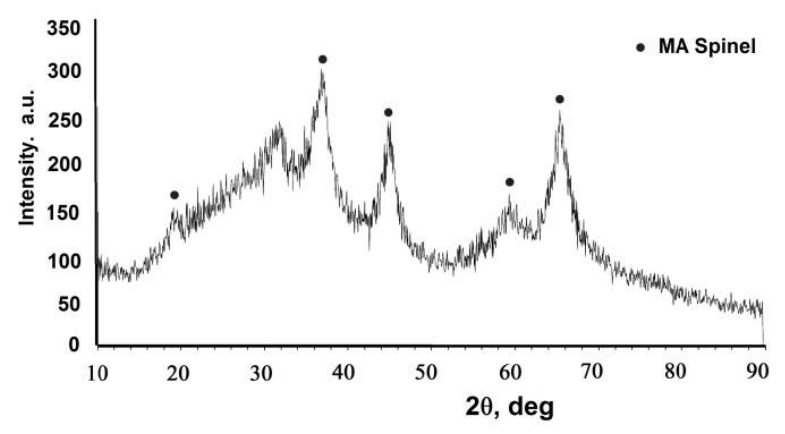

Fig. 1. XRD pattern of as-synthesized magnesium aluminate spinel
As can be seen from this pattern, a pure MA spinel phase is synthesized. XRD patterns with broad background are normally found in powders where synthesized from precipitation method [14]. Thus crystalline phases are mixed with amorphous solid within the as-precipitated MA spinel sample.

FTIR spectroscopies of the mixture of spinel and iron chloride, before and after the calcination process are shown in Fig. 2. Before calcination, strong absorption bands in region $3800-3200 \mathrm{~cm}^{-1}$ and $1700-1600 \mathrm{~cm}^{-1}$ are resulted from hydration of iron chloride stretching and bending motions of H-O-H bands, respectively. Besides, the broad band centered at $3400 \mathrm{~cm}^{-1}$ is related to hydroxyl groups [15]. Moreover, absorption band in range $900-430 \mathrm{~cm}^{-1}$ may be due to Al-O stretching motions [16]. After heating the specimen at $400{ }^{\circ} \mathrm{C}$ for $3 \mathrm{hrs}$, the intensity of hydroxyl peaks decreases but there are still short absorption peaks, which indicates small amounts of persisted hydrates in the specimen (Fig. 2). The result of EDX chemical spectroscopy analyzing of this sample is indicated that the chlorine of the sample at was removed, when it was heated at $800{ }^{\circ} \mathrm{C}$ for $3 \mathrm{hrs}$.

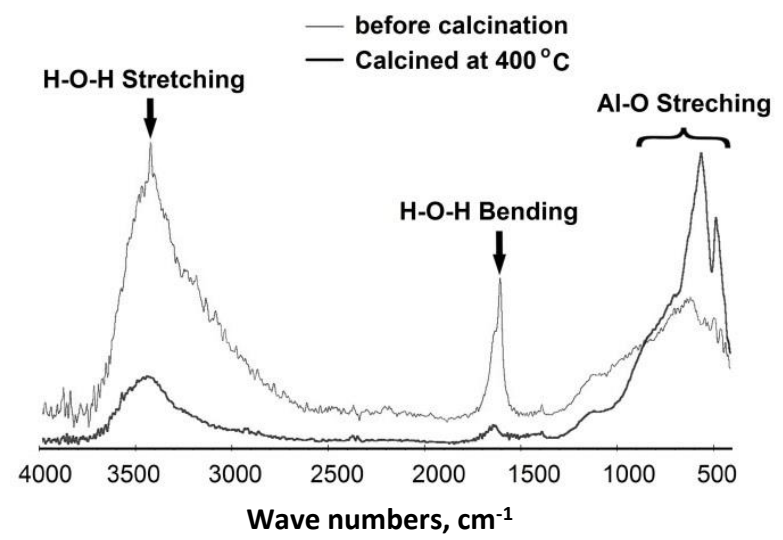

Fig. 2. FTIR spectroscopy spectra of the specimen (the mixture of spinel and iron chloride) before and after the heating at $400{ }^{\circ} \mathrm{C}$ for $3 \mathrm{hrs}$

Simultaneous thermal analysis and thermo-gravimetery analysis of this sample are also measured and the results are shown in Fig. 3.

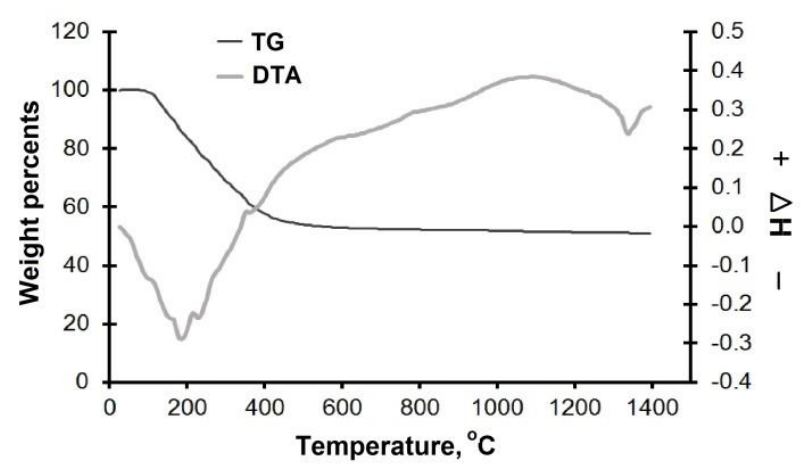

Fig. 3. Simultaneous STA/TG thermal curves of the mixture of spinel and iron chloride

Fig. 4 show the XRD patterns of the specimens calcined at various temperatures for $3 \mathrm{hrs}$. The peaks of hematite and spinel phases remain unchanged in the spectra of specimens until $1100^{\circ} \mathrm{C}$. With increasing the temperature until 
$1100{ }^{\circ} \mathrm{C}$, the existing phases in the sample are remained unchanged, as the results of EDX chemical analysis was confirmed. Comparing Fig. $4 \mathrm{~b}$ and a as well as $\mathrm{d}$ and c, one can conclude that present phases do not change, when the time of heating prolonged from 3 to $6 \mathrm{hrs}$. In contrast, it was found that increasing temperature of calcination leads to some changes in the XRD patterns and so it was concluded that increasing the calcination temperature would favor formation of hercynite. When the calcination temperature is increased and reached to $1100{ }^{\circ} \mathrm{C}$, corundum peaks appear in the XRD pattern and intensity of hematite peaks decrease (Fig. 4 c). As spinel heated up to $1100{ }^{\circ} \mathrm{C}$, the aluminum diffuses out of its structure, as the only source of aluminum atoms, and forms corundum phase [17]. Besides, quantities of phases of the specimens calcined at 800 to $1100{ }^{\circ} \mathrm{C}$ were calculated from the XRD patterns, using Rietveld method (MAUD software). The results show that the amount of spinel does not change while the values of Hematite reduces during higher temperature calcination of the specimen. So, one can conclude that iron cations diffused from hematite into spinel structure [10, 18].

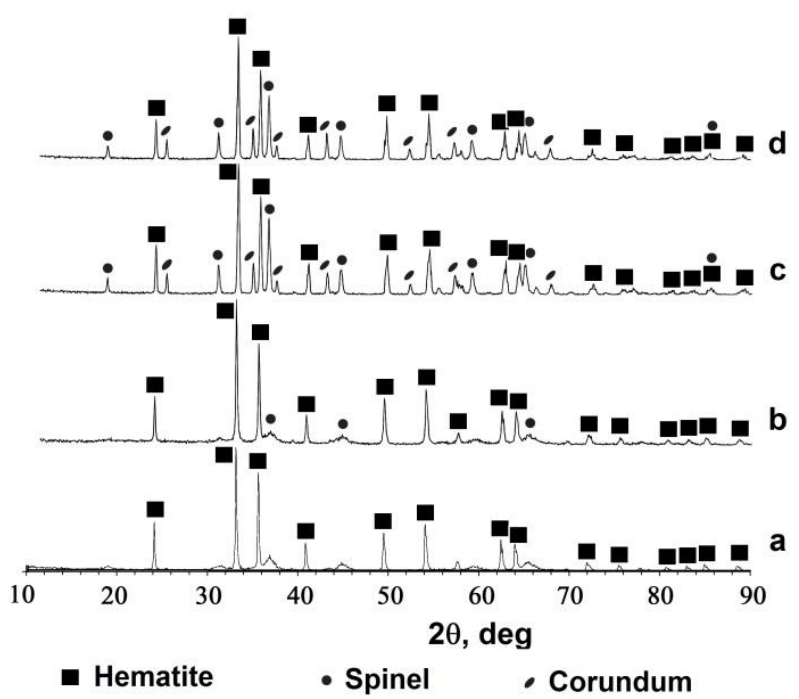

Fig. 4. XRD patterns of the specimens calcined at $800{ }^{\circ} \mathrm{C}$ for $3 \mathrm{hrs}$ (a) and $6 \mathrm{hrs}$ (b) as well as that of the specimens calcined at $1100{ }^{\circ} \mathrm{C}$ for $3 \mathrm{hrs} \mathrm{(c)} \mathrm{and} 6 \mathrm{hrs} \mathrm{(d)}$

There were also not observed a detectable change in the XRD measurement, when the sintering temperature is raised to $1300{ }^{\circ} \mathrm{C}$. Fig. 5 compares the XRD patterns of the specimens calcined at $1400{ }^{\circ} \mathrm{C}$ for 1,3 and $6 \mathrm{hrs}$. There are not any peaks of MA spinel and corundum phases and the peaks of hercynite are clearly visible in the XRD spectra of the sample calcined for $1 \mathrm{hr}$ (Fig. 5 a). The composition of this specimen is shown in Table 1.

Table 1. The chemical composition of hercynite powder, wt.\%

\begin{tabular}{|c|c|c|c|c|c|}
\hline $\mathrm{Al}_{2} \mathrm{O}_{3}$ & $\mathrm{Fe}_{2} \mathrm{O}_{3}$ & $\mathrm{MgO}$ & $\mathrm{SiO}_{2}$ & $\mathrm{CaO}$ & $\mathrm{Na}_{2} \mathrm{O}$ \\
\hline 43.97 & 37.01 & 15.84 & 2.06 & 0.93 & 0.05 \\
\hline
\end{tabular}

Besides, there are slight peaks of hematite along with hercynite, indicating that some hematite remained during the reaction sintering period. The data would seem to suggest that the mixing of the starting materials in the solution state leads to formation of a rather homogeneous mixture and thus, it could be expected that a lower processing temperature. This could be due to superior reaction between raw materials, because of their higher contact surface area between the components, than that of the custom mixing method.

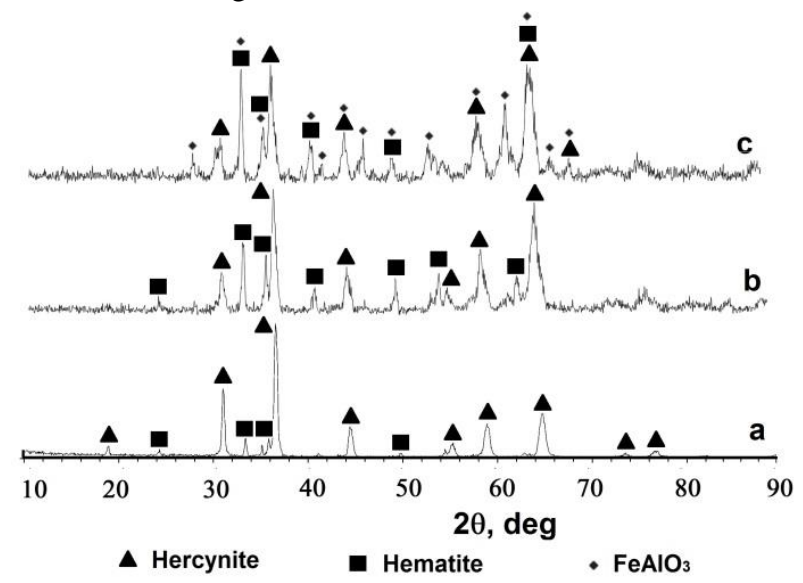

Fig. 5. XRD patterns of the specimens calcined at $1400{ }^{\circ} \mathrm{C}$ for $1 \mathrm{hr}(\mathrm{a}), 3 \mathrm{hrs} \mathrm{(b)}$ and $6 \mathrm{hrs} \mathrm{(c)}$

On the other hand, when comparing the XRD patterns of Fig. 5, the peak intensity of hercynite decrease and a new phase appears. Annealing of hercynite for a long time at a high temperature in air leads to alteration of its phase composition [10]. In conjunction with the mentioned decomposition, a crystal phase appears, indicating a phase change. The chemical formula of this new phase was identified as $\mathrm{FeAlO}_{3}$.

The intensity of (042) plane of $\mathrm{FeAlO}_{3}$ in the XRD patterns of sintered hercynite for various time was used as a direct indicator of kinetic of formation of $\mathrm{FeAlO}_{3}$ at 1400 ${ }^{\circ} \mathrm{C}$. In this respect, after sintering the ratios of the peak intensities of $\mathrm{FeAlO}_{3}$ and hercynite in the XRD patterns $\left(I_{(042) \mathrm{FeAlO} 3} / I_{(311) \text { Hercynite }}\right)$ were extracted from XRD patterns of Fig. 5. These values of sintered samples vs. sintering duration at $1400{ }^{\circ} \mathrm{C}$, are presented in Fig. 6 .

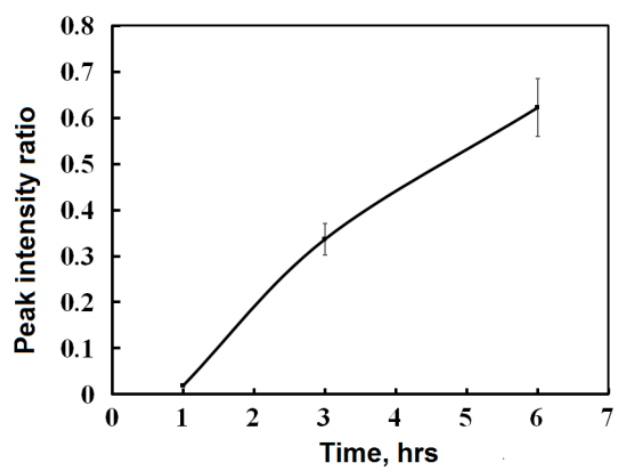

Fig. 6. The relative intensity of (042) plane of $\mathrm{FeAlO}_{3}$ (two teta $=53.86^{\circ}$ ) on (311) plan of hercynite (two teta $=36.63^{\circ}$ ) in XRD patterns of synthesized specimens after sintering at $1400{ }^{\circ} \mathrm{C}$ at various times

From these results, it seems most likely that formation of $\mathrm{FeAlO}_{3}$ is most probably the result of decomposition of hercynite and it seems a time dependent mechanism. It also could be explained by thermodynamic evaluation. $\mathrm{FeAlO}_{3}$ can be formed from aluminum and iron oxides as shown in the following reaction:

$\mathrm{Al}_{2} \mathrm{O}_{3}(\mathrm{~s})+\mathrm{Fe}_{2} \mathrm{O}_{3}(\mathrm{~s})=\mathrm{FeAlO}_{3}(\mathrm{~s})$. 
Because $\Delta G=-71086+11.89 \mathrm{~T}$, when the temperature increased, $\Delta G<0$, and so $\mathrm{Fe}_{2} \mathrm{O}_{3}$ reacts with $\mathrm{Al}_{2} \mathrm{O}_{3}$, forming $\mathrm{FeAlO}_{3}$ [18]. Consequently, under increasing time and/or temperature, the $\mathrm{FeAlO}_{3}$ spinel content increased (see Fig. 6). Hematite and corundum have the same crystalline structure, which favors the formation of solid solutions between the two end members [18]. A recent review of the literature on the issue associated with the temperature range of stability of ternary Al-Fe-O system [20] showed that the $\mathrm{AlFeO}_{3}$ oxide could be stable together with two corundum phases and the spinel phase in the rang $800-1495^{\circ} \mathrm{C}$. Majzlan et al suggested that, although all optimized $\mathrm{FeAlO}_{3}$ structures are higher in energy than a mechanical mixture of hematite and corundum, but the slow diffusion of ions through the structure prohibits the structure to achieve any lower-energy, ordered state, even at $1500{ }^{\circ} \mathrm{K}$ and at low temperatures, when the driving force for ordering might increase [17]. Meanwhile, $\mathrm{MgAl}_{2} \mathrm{O}_{4}$ can be formed from aluminum and magnesium oxides as shown in the following reaction [21]:

$$
\mathrm{Al}_{2} \mathrm{O}_{3}(\mathrm{~s})+\mathrm{MgO}(\mathrm{s})=\mathrm{MgAl}_{2} \mathrm{O}_{4}(\mathrm{~s}) \text {. }
$$

As Tong et al [22] recently reported, because for the above reaction: $\Delta G=-23604-5.91 T$, and under increasing temperature: $\Delta G<0$, thus $\mathrm{MgO}$ reacts with $\mathrm{Al}_{2} \mathrm{O}_{3}$, forming $\mathrm{MgAl}_{2} \mathrm{O}_{4}$, and hence the $\mathrm{MgAl}_{2} \mathrm{O}_{4}$ spinel content also increases. Given that $\mathrm{Mg}$-containing spinel has similar elemental compositions and that their crystal boundaries can be partly fused together, they are impossible to distinguish in SEM images, as confirmed by the XRF results in Table. 1 .

The crystallite sizes of the hercynite, which was calcined at $1400{ }^{\circ} \mathrm{C}$ for $1 \mathrm{hr}$, were also estimated, using different XRD-based methods. The calculated crystallite sizes were about 28.1, 57.7 and $84 \mathrm{~nm}$, using modified Scherrer, Williamson-Hall and Rietveld methods, respectively. This confirms that the crystalline size of the produced hercynite solid solution is less than $100 \mathrm{~nm}$.

Further tests carried out with FESEM method corroborated with our initial findings. Micrographs of specimens calcined at different temperature and times are shown in Fig. 7. The micrograph of the sample calcined at lower temperatures than $1400{ }^{\circ} \mathrm{C}$ show spinel and hematite particles, which have hexagonal and spherical features [12], respectively (see Fig. $7 \mathrm{a}, \mathrm{b}, \mathrm{c}$, e and f). As the XRD examinations showed, many ultra-fine rectangular particles of hercynite were formed (see Fig. $7 \mathrm{~d}$, g and h), when calcination was carried out at $1400{ }^{\circ} \mathrm{C}$. The micrograph of Fig. $7 \mathrm{~g}$ shows well crystallized grains of hercynite are formed and connected with each other, indicating that the nano-crystaline hercynite was synthesized, when the specimens calcined at $1400{ }^{\circ} \mathrm{C}$ for $1 \mathrm{hr}$. With microstructural evaluation of the specimens calcined at $1400{ }^{\circ} \mathrm{C}$ for 1 and $6 \mathrm{hrs}$ (in Fig. $7 \mathrm{~h}$ and g, respectively), one can see that, upon prolonged heating at this temperature, not only the grain size of the formed hercynite is increased, but also very fine new particles $\left(\mathrm{FeAlO}_{3}\right)$ are appeared.

MA spinel crystal structure, as a normal spinel, is made by a primitive cubic that contains eight FCC unit cells. In this structure, oxygen anions make FCC units and among 32 octahedral sites, one half of them are occupied by $\mathrm{Al}^{3+}$. Also $\mathrm{Mg}^{2+}$ occupies only one eighth of 64 tetrahedral sites [4, 7].
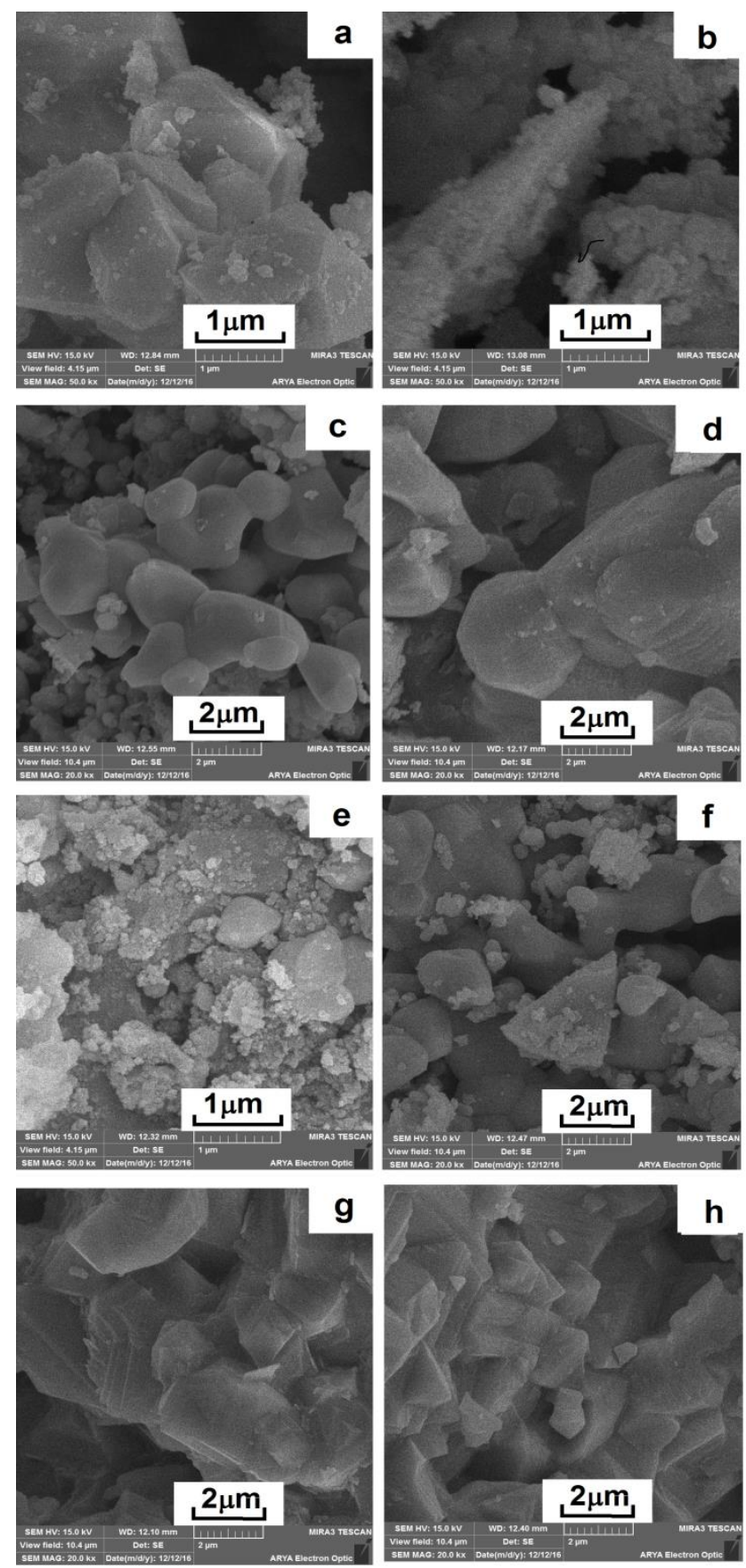

Fig. 7. FESEM images of calcined specimens for $3 \mathrm{hrs}$ at $400{ }^{\circ} \mathrm{C}$ (a), $800{ }^{\circ} \mathrm{C}(\mathrm{b}), 1100{ }^{\circ} \mathrm{C} \mathrm{(c),} 1400{ }^{\circ} \mathrm{C}(\mathrm{d})$, and for $6 \mathrm{hrs}$ at $800{ }^{\circ} \mathrm{C}(\mathrm{e}), 1100{ }^{\circ} \mathrm{C}(\mathrm{f}), 1400^{\circ} \mathrm{C}(\mathrm{g})$, and for $1 \mathrm{hr}$ at $1400{ }^{\circ} \mathrm{C}(\mathrm{h})$

There are many tetrahedral sites in spinel crystal lattice hence entering iron (II) cations into the tetrahedral sites makes no changes in magnesium atoms location $[4,7,10]$. So, the hercynite-magnesium solid solution formed, when aluminum atoms occupied octahedral sites and iron and magnesium atoms located in tetrahedral sites [4,7]. The arguments given above prove that, the following mechanism could be suggested for formation of the hercynite-based solid solution: Iron chloride is deposited on the surface of particles of MA spinel powder, when the solution of iron chloride was dried. During the calcination of the samples at $400{ }^{\circ} \mathrm{C}$, the structural water of the composition eliminates. Furthermore, the chlorides remove after heating above 
$430{ }^{\circ} \mathrm{C}$. The composition of the hematite and spinel phases does not change in the specimens, which heated to about $800{ }^{\circ} \mathrm{C}$.

At $1100{ }^{\circ} \mathrm{C}$, iron cations diffuse into the MA spinel crystal lattice and replace aluminum atoms in the octahedral sites. The released $\mathrm{Al}$ atoms exit from their location and form corundum phase. So, phase composition of the calcined specimen at $1100{ }^{\circ} \mathrm{C}$ consists of spinel, hematite and corundum. As the temperature increases to $1400{ }^{\circ} \mathrm{C}$, iron atoms move to the tetrahedral sites in the spinel structure, where the magnesium cations are existing. So, aluminum cations can return to the octahedral cation sites of spinel structure. In this process, MA spinel prepares a suitable base for iron cations. Diffusion of iron inside the spinel leads to formation of hercynite-magnesium solid solution under air atmosphere. As stated in the literature review, the common synthesis process of hercynite needs a reduction atmosphere to change iron valence, which leads to inter reaction between iron oxide and corundum. In contrast with the stated reduction process, only the direct diffusion and mentioned replacements of the cations in the exciting structure of the spinel, makes the formation of hercynite possible. However, some experimental justification (such as Mössbauer spectroscopy) for such a theoretical assumption is needed.

\section{CONCLUSION}

In this study, nano-crystalline hercynite-magnesium solid solution was synthesized in air atmosphere at $1400{ }^{\circ} \mathrm{C}$, using magnesium aluminate spinel and iron chloride as precursors. Hercynite is usually prepared under inert or reduction atmosphere with partial pressure of oxygen. The results showed that during reaction sintering of MA spinel, which was dispersed in iron chloride solution, a magnesium doped hercynite (or a hercynite-based solid solution) is formed. Study of the obtained results leads us to conclude that hercynite was formed thorough a diffusion-based mechanism, when heated to high enough temperatures. Moreover, the synthesized hercynite decomposed into aluminum and iron oxides, when subjected to a prolonged heating period $(6 \mathrm{hr})$ at $1400{ }^{\circ} \mathrm{C}$. This decomposition could offer an insight into the formation mechanism of $\mathrm{FeAlO}_{3}$ from the mentioned oxides. Although this offered mechanism is not entirely clear to be proposed, however, this study serves as a beginning for further research. To sum up, this study serves as a windows to gain an understanding of benefits of using of wet mixing process in the reaction sintering synthesis of hercynite, such as a shorter mixing time and calcination period as well as higher efficiency than that of common method.

\section{REFERENCES}

1. Jaecheol, Y., Yangdo, K. Preparation of Iron Aluminate $\left(\mathrm{FeAl}_{2} \mathrm{O}_{4}\right)$ Nanoparticles from $\mathrm{FeAl}_{2} \mathrm{O}_{4}$ Hollow Particles Fabricated by using a Spray Pyrolysis Process Journal of the Korean Physical Society 66 (10) 2015: pp. 1503-1507.

2. Fukushima, J., Yamato, H., Hirotsugu, T. Structure and Magnetic Properties of $\mathrm{FeAl}_{2} \mathrm{O}_{4}$ Synthesized by Microwave Magnetic Field Irradiation Journal of Asian Ceramic Societies 1 (1) 2013: pp. $41-45$. https://doi.org/10.1016/j.jascer.2013.02.001
3. Pablo, M.B., Esteban, F.A., José, M.P. Mechanochemical Synthesis of Hercynite Materials Chemistry and Physics 76 (1) 2002: pp. 104-109. https://doi.org/10.1016/S0254-0584(01)00505-3

4. Chen, J., Yu, L., Sun, J., Li, Y., Xue, X. Synthesis of Hercynite by Reaction Sintering Journal of the European Ceramic Society 31 (3) 2011: pp. 259-263. https://doi.org/10.1016/j.jeurceramsoc.2010.09.017

5. Rodri'guez, E., Castillo, G., Contreras, J., Puente-Ornelas, R., Aguilar-Martı'nez, J.A., Garcı'a, L., Go'mez, C. Hercynite and Magnesium Aluminate Spinels Acting as a Ceramic Bonding in an Electrofused $\mathrm{MgO}-$ $\mathrm{CaZrO}_{3}$ Refractory Brick for the Cement Industry Ceramics International 38 (8) 2012: pp. 6769-6775. https://doi.org/10.1016/j.ceramint.2012.05.071

6. Andreozzi, G.B., Baldi, G., Bernardini, G.P., Benedetto, F.D., Maurizio Romanelli, M. ${ }^{57} \mathrm{Fe}$ Mo ${ }^{*}$ ssbauer and Electronic Spectroscopy Study on a New Synthetic Hercynite-Based Pigment Journal of the European Ceramic Society 24 (5) 2004: pp. 821-824. https://doi.org/10.1016/S0955-2219(03)00329-7

7. Dutta, D.P., Sharma, G. Synthesis and Magnetic Behavior of Spinel $\mathrm{FeAl}_{2} \mathrm{O}_{4}$ Nanoparticles Materials Science and Engineering 176 (2) 2011: pp. 177-180. https://doi.org/10.1016/j.mseb.2010.10.018

8. Jastrzębska, I., Szczerba, J., Blachowski, A., Stoch, P., Structure and microstructure evolution of hercynite spinel $\left(\mathrm{Fe}_{2}+\mathrm{Al}_{2} \mathrm{O}_{4}\right)$ after annealing treatment European Journal of Mineralogy 29 2017; pp. 63-72. https://doi.org/10.1127/ejm/2017/0029-2579

9. Sako, E.Y., Braulio, M.A.L., Zinngrebe, E., van der Laan, S.R., Pandolfelli, V.C. Fundamentals and Applications on in situ Spinel Formation Mechanisms in $\mathrm{Al}_{2} \mathrm{O}_{3}-\mathrm{MgO}$ Refractory Castables Ceramics International 38 (3) 2012: pp. 2243-2251. http://doi.org/10.1016/j.ceramint.2011.10.074

10. Jastrzębska, I., Jacek, S., Blachowsk, A., Pawel, S. Structure and Microstructure Evolution of Hercynite Spinel $\left(\mathrm{Fe}^{2+} \mathrm{Al}_{2} \mathrm{O}_{4}\right)$ After Annealing Treatment European Journal of Mineralogy 29 (1) 2017: pp. 63-72. https://doi.org/10.1127/ejm/2017/0029-2579

11. Otroj, S. Synthesis of Hercynite under Air Atmosphere using $\mathrm{MgAl}_{2} \mathrm{O}_{4}$ Spinel Materials Science (Medžiagotyra) 21 (2) 2015: pp. $288-292$.

https://dx.doi.org/10.5755/j01.ms.21.2.5866

12. Baghaei, A., Otroj, S., Baghshahi, S., Mohebi, M.M. Impact of $\mathrm{MgCl}_{2}$ Addition on the Formation of NanoCrystalline Hercynite Synthesized by Co-Precipitation Method Ceramics - Silikáty 59 (3) 2015: pp. 220-226.

13. Li, J.G., Ikegami, T., Lee, J.H., Mori, T., Yajima, Y. Synthesis of $\mathrm{Mg}-\mathrm{Al}$ Spinel Powder via Precipitation using Ammonium Bicarbonate as the precipitant Journal of the European Ceramic Society 21 (2) 2001: pp. 139-148. https://doi.org/10.1016/S0955-2219(00)00188-6

14. Santolall, C., Chavez-Esquive, G. de los ReyesHeredi, J.A., Alvarez-Ramirez, J. Fractal Correlation Analysis of X-ray Diffraction Patterns with Broad Background Industrial \& Engineering Chemistry Research 52 (24) 2013: pp. 8346-8353. https://doi.org/10.1021/ie303069y

15. Derrick, M.R., Stulik, D.J., Landry, M. Infrared Spectroscopy in Conservation Science Getty Publications 2000. 
16. Naskar, M.K., Chatterjee, M. Magnesium Aluminate (MgAl2O4) Spinel Powders from Water-Based Sols Journal of American. Ceramic Society 88 (1) 2005: pp 38-44. https://doi.org/10.1111/j.1551-2916.2004.00019.x

17. Majzlan, J., Navrotsky, A., Evans, B.J. Thermodynamics and Crystal Chemistry of the Hematite-Corundum Solid Solution and the $\mathrm{FeAlO}_{3}$ phase Physics and Chemistry of Minerals 29 2002: pp. 515-526. https://doi.org/10.1007/s00269-002-0261-7

18. Shishin, D., Prostakova, V., Jak, E., Decterov, S.A. Critical Assessment and Thermodynamic Modeling of the Al-Fe-O System Metallurgical and Materials Transactions 47 (1) 2016: pp. 397-424.

https://doi.org/10.1007/s11663-015-0493-9

19. Zoppi, A., Lofrumento, C., Castellucci, E.M., Sciau, Ph. Al-for-Fe Substitution in Hematite: The Effect of Low Al Concentrations in The Raman Spectrum of $\mathrm{Fe}_{2} \mathrm{O}_{3}$ Journal of Raman Spectroscopy 39 2008: pp. 40-46. https://doi.org/10.1002/jrs.1811
20. Lindwall, G., Liu, X.L., Ross, A., Fang, H., Zhou, B.C., Liu, Z. K. Thermodynamic Modeling of the AluminumIron-Oxygen System CALPHAD: Computer Coupling of Phase Diagrams and Thermochemistry 51 2015: pp. $178-192$. https://doi.org/10.1016/j.calphad.2015.09.004

21. Chen, J., Yan, M., Su, J., Li, B., Sun, J., Chou, K.C., Hou, X. Effect of $\mathrm{SiO}_{2}$ addition on the synthesis of hercynite with high purity Journal of the Ceramic Society of Japan 123 (7) 2015: pp. 595-600. https://doi.org/10.2109/jcersj2.123.595

22. Tong, S.H., Li, Y., Yan, M.W., Jiang, P., Ma, J.J., Yue, D.D. In Situ Reaction Mechanism of MgAlON in $\mathrm{Al}-$ $\mathrm{Al}_{2} \mathrm{O}_{3}-\mathrm{MgO}$ Composites at $1700^{\circ} \mathrm{C}$ under Flowing $\mathrm{N}_{2}$ International Journal of Minerals, Metallurgy and Materials 24 (9) 2017: pp. 1061 - 1066.

https://doi.org/10.1007/s12613-017-1496-0 